REPORT

\title{
Psoriasis treatment: current and emerging directed therapies
}

\author{
L S Winterfield, A Menter, K Gordon, A Gottlieb
}

Ann Rheum Dis 2005;64(Suppl II):ii87-ii90. doi: 10.1136/ard.2004.032276

Quality of life studies in patients with cutaneous psoriasis attest to its significant impact on day to day activities and personal social interactions. Up to $40 \%$ of patients with psoriasis may develop psoriatic arthritis, usually within 5-10 years after onset of the cutaneous disease, heightening quality of life issues. These data have prompted an increased awareness and interest in more aggressive management of psoriasis; coupled with a better understanding of immunopathogenesis, this has led to the development of new agents targeting specific cells and molecules involved in the development and maintenance of psoriatic plaques. Although non-biological therapies, including methotrexate and ciclosporin, show significant efficacy their side effect profiles have precluded their long term use for moderate to severe psoriasis. This review concentrates on new biological agents, focusing on the three agents approved for psoriasis within the past 18 months (alefacept, efalizumab, and etanercept). Phase II and III trial data on other agents in development (adalimumab and infliximab) are also presented. Surveys show many patients want to be treated more aggressively. It is hoped that the introduction of new agents that are more targeted and that hold the promise of fewer side effects will cause patients and their physicians to reconsider systemic treatment and, as a consequence, stimulate other patients to reconsider treatment for psoriasis. Close cooperation between dermatologists and rheumatologists, particularly in the area of psoriatic joint disease, will enhance these considerations.

$\mathrm{P}$ soriasis vulgaris is a lifelong, chronic, immune mediated, inflammatory skin condition affecting approximately $2 \%$ of the general population. ${ }^{1}$ Although there are several clinical variations of psoriasis, the typical skin lesions are well defined, red, indurated plaques with silver, micaceous scale. The clinical features of plaque psoriasis vary due to many factors, including chronicity of disease, size of the lesions, body sites, percentage of body surface area (BSA) involved, symptomatology, such as pruritus, burning, or pain, associated joint disease, and prior therapy. ${ }^{2}$ Psoriasis commonly presents before the age of 35 years and has no known cure. Quality of life issues in psoriasis often exceed those of many of the chronic diseases.

\section{MEASURING SEVERITY OF DISEASE}

The US Food and Drug Administration (FDA) defines mild, moderate, and severe psoriasis based on BSA involvement, arbitrarily defining "severe" disease as involving $20 \%$ or more of the patient's BSA. To measure therapeutic benefit for the recently approved "biologicals", the FDA has encouraged the use of change in the Psoriasis Area and Severity Index (PASI) to assess efficacy. PASI is a composite scoring system that takes into account lesional erythema, induration and scale, and the BSA affected in four specific body regions (head and neck, trunk, and upper and lower extremities). However, recent studies have shown that BSA and PASI do not correlate well with the impact of the disease on patients' quality of life..$^{4-8}$ In response to these findings, the Medical Advisory Board of the National Psoriasis Foundation proposed new criteria for the classification of mild, moderate, and severe disease that include the impact of disease on patients. ${ }^{9}$ It is felt that the criteria set forth-which are largely quality of life based-should be the primary consideration when determining the therapeutic regimen for a given patient.

\section{IMMUNOLOGY}

Observations from animal models of psoriasis and treatment with $\mathrm{T}$ cell specific inhibitors, such as ciclosporin, point to $\mathrm{T}$ cells as the driving force in inducing and maintaining the phenotypic changes seen in psoriasis. ${ }^{10-19}$ This concept is supported by histological and immunohistochemical examinations of lesional skin, which reveal infiltration of $\mathrm{T}$ lymphocytes in the dermis and epidermis. The $\mathrm{T}$ cell infiltrate is primarily activated by memory effector T cells. ${ }^{20}{ }^{21}$ To reach the effector state, $\mathrm{T}$ cells must first be activated by antigen presenting cells (APCs), such as dendritic cells. The specific antigen(s) involved in the interaction between $\mathrm{T}$ cells and APCs, apart from a few infections, such as streptococcal, are unknown. Further details of the pathogenesis of psoriasis are discussed in this supplement by Krueger and Bowcock. ${ }^{22}$

\section{BIOLOGICALS}

Elucidation of the immunopathogenesis of psoriasis has led to the emergence of new therapies targeting the immune cells and molecules that induce and maintain the clinical changes seen in psoriatic plaques. Biological agents are proteins derived from recombinant DNA technology, hybridomas, blood, and whole human cells. In psoriasis, these agents are designed to specifically interfere with $\mathrm{T}$ cell activation and effector functions. Many of these drugs are also effective in treating psoriatic arthritis (PsA).

Several strategies are used to block the induction or maintenance of $\mathrm{T}$ cell activation in psoriatic disease. ${ }^{23}$ The first is to reduce the number of pathogenic T cells. Alefacept employs this strategy. It is a fusion protein composed of leucocyte function associated antigen (LFA)-3 with the FC portion of human IgG. Alefacept binds to CD2 on T cells to block costimulation or signal 2 by preventing CD2 from binding LFA-3 on APCs. ${ }^{2-26}$ It also triggers apoptosis of activated memory $\mathrm{T}$ cells expressing high levels of CD2 via binding of Fc $\gamma$ RIII IgG receptors on natural killer cells and macrophages. ${ }^{27}$ Alefacept has been approved by the FDA for

Abbreviations: APC, antigen presenting cell; BSA, body surface area; FDA, Food and Drug Administration; PASI, Psoriasis Area and Severity Index; PsA, psoriatic arthritis 
the treatment of moderate to severe psoriasis as a 12 week course of $15 \mathrm{mg}$ weekly intramuscular injections. In clinical trials of a 12 week course of therapy, $33 \%$ of patients achieved PASI 75 (75\% improvement in baseline PASI score) and $57 \%$ of patients achieved PASI 50 at some time during the 24 week study period. ${ }^{28}$ A proportion of responding patients enjoyed long remissions from their psoriasis. Alefacept has also been shown to decrease synovial tissue T cell and macrophage infiltration in PsA. ${ }^{29}$ The most significant laboratory abnormality with this medication is reduction of the CD4 count, with a theoretical concomitant increased risk of infection. However, no increases in infections have been seen in clinical trials of alefacept. Nonetheless, in clinical practice, patients are monitored with weekly CD4 counts while on the drug. The weekly dose is withheld for a CD4 count of less than 250 cells/ $\mu$, and therapy is discontinued if the CD4 count remains below 250 cells $/ \mu$ l for more than four weeks. A second course extends the period of remission without additional risk of adverse events. Preliminary data show that concomitant ultraviolet light appears to speed the response and that extending the dose to 16 weeks causes more patients to have clinically meaningful improvement.

The second strategy is blockade of T cell activation and/or migration. Efalizumab is a humanised monoclonal antiCDlla antibody that binds to the CDlla portion of human LFA- 1 and blocks the LFA-1/ intercellular adhesion molecule (ICAM) interaction, thus blocking both signal 2 and $\mathrm{T}$ cell migration. ${ }^{30-32}$ Response to efalizumab has also recently been shown to correlate with a decreased number of dendritic cells. ${ }^{33}$ Efalizumab has been approved by the FDA for the treatment of moderate to severe psoriasis. In phase III clinical trials, $27 \%$ of patients who were given efalizumab as a $1.0 \mathrm{mg} / \mathrm{kg}$ weekly subcutaneous injection for 12 weeks achieved PASI $75 .{ }^{34}$ Efalizumab has not been shown to be effective in treating PsA. The commonest side effects were headache, chills, fever, nausea, vomiting, or myalgia occurring on the day of injection or in the following two days during the initial three weeks of therapy. Adverse effects associated with this drug are a "rebound" phenomenon post discontinuation of therapy ( $14 \%$ of patients) and a worsening of disease in unresponsive patients during therapy. In some cases, the rebound may present as a different clinical subtype of psoriasis. ${ }^{35}$ Careful monitoring of unresponsive patients, especially during weeks 6-12 of therapy, as well as transitioning patients to alternative forms of therapy while slowly tapering efalizumab, may minimise this risk. In open trials, continuous weekly treatment data show that nearly $44 \%$ will achieve a $75 \%$ reduction in PASI by 24 weeks.

The third strategy for biological agents to treat psoriasis involves induction of immune deviation, a shift from $\mathrm{T}$ cell production of $\mathrm{T}$ helper (Th) 1 to Th 2 type cytokines. T cells in psoriasis produce a predominantly Th 1 cytokine profile. ${ }^{36}$ Theoretically, inducing a switch from a Th 1 to Th 2 profile could alleviate psoriatic disease. One approach has been to use Th 2 cytokines, such as interleukin (IL)-4, IL-10, or IL-1 1, to tilt the balance and inhibit the Th 1 response. Alternatively, specific cytokine antagonists may prevent $\mathrm{T}$ cell differentiation towards the Th 1 phenotype. One such antagonist drug is CNTO-1275, an anti-IL-12 p40 monoclonal antibody that inhibits the action of IL-12, a crucial cytokine involved in differentiation of Th 1 cells. It also inhibits IL-23, another cytokine recently shown to be involved in the pathogenesis of psoriasis. ${ }^{37}$ This drug is currently in early stages of phase II trials.

The final strategy involves inactivation of secreted effector cytokines. Tumour necrosis factor $\alpha(\mathrm{TNF} \alpha)$ appears to be a critical cytokine for many of the clinical features of psoriasis, including keratinocyte hyperproliferation, endothelial cell regulation, and recruitment/effector function of memory $\mathrm{T}$ cells. Several anti-TNF drugs have been used successfully to treat psoriasis and PsA.

Infliximab, a chimeric anti-TNF monoclonal antibody administered by intravenous infusion, was the first TNF blocker studied for the treatment of psoriasis. Infliximab has been approved by the FDA for the treatment of moderate to highly active rheumatoid arthritis (in combination with methotrexate) and moderate to highly active Crohn's disease or for those patients with Crohn's and rheumatoid arthritis who have failed to respond to conventional treatment. In subsequent placebo controlled trials, infliximab has been given as monotherapy for psoriasis at $3 \mathrm{mg} / \mathrm{kg}, 5 \mathrm{mg} / \mathrm{kg}$, and $10 \mathrm{mg} / \mathrm{kg}$ doses, initiated with an induction regimen of infusions at 0,2 , and 6 weeks, followed by maintenance dosing every eight weeks. At a dose of $5 \mathrm{mg} / \mathrm{kg}$ per infusion in the phase II trial, $87.9 \%$ of patients achieved a $75 \%$ reduction in PASI at 10 weeks. ${ }^{38}$ The commonest side effects with infliximab were headaches and infusion reactions, the vast majority of which were classified as mild. Another concern is increased risk of opportunistic infection, especially tuberculosis. Most of the data regarding this risk come from patients with rheumatoid arthritis and Crohn's disease. Patients who are candidates for this treatment must have tuberculosis skin testing prior to the initiation of therapy to avoid reactivation of latent tuberculosis. Additionally, patients should be strongly advised to be vigilant for early signs of infection. Because infliximab is a chimeric antibody, there is the potential for development of neutralising antibodies. Anti-infliximab antibodies were measured in the phase II psoriasis trial (induction therapy at 0,2 , and 6 weeks). At week 26, 27.5\% of patients in the $3 \mathrm{mg} / \mathrm{kg}$ group and $19.5 \%$ of patients in the $5 \mathrm{mg} / \mathrm{kg}$ group had detectable antibody titres. The current phase III one year clinical study will help to determine whether infliximab will retain its efficacy as monotherapy over longer periods of time.

Other biological drugs, including those that are "humanised" or "fully human" also exhibit some immunogenicity when administered to human patients; the clinical relevance of antibody development to each of these drugs remains to be determined in long term studies.

Etanercept is a TNF $\alpha$ receptor fusion protein administered by twice weekly subcutaneous injection. It is the only antiTNF drug currently approved by the FDA for the treatment of cutaneous psoriasis. It is also approved for the treatment of rheumatoid arthritis, ankylosing spondylitis, juvenile rheumatoid arthritis, and PsA. In clinical trials, etanercept administered at a dose of $25 \mathrm{mg}$ subcutaneously twice weekly achieved a PASI 75 of $30-34 \%$ at 12 weeks and 44 $56 \%$ at 24 weeks. $^{39} 40$ At a dose of $50 \mathrm{mg}$ subcutaneously twice weekly, the PASI 75 response increased to $49 \%$ at 12 weeks and $59 \%$ at 24 weeks. ${ }^{40}$ The commonest side effect of etanercept was reaction at the site of injection. As with other anti-TNF drugs, the potential increased risk of infection is a concern. In controlled trials, the rates of infections were not different from those in patients treated with placebo or methotrexate. ${ }^{3814} 42$ However, post marketing surveillance has included reports of serious and, rarely, fatal infections in patients treated with anti-TNF agents.

Adalimumab is a fully humanised anti-TNF monoclonal antibody administered as $40 \mathrm{mg}$ subcutaneously once every other week. It has been approved by the FDA for the treatment of rheumatoid arthritis. Recently completed phase II clinical trials in the treatment of psoriasis showed impressive PASI responses, with $53 \%$ of patients on $40 \mathrm{mg}$ every other week and $80 \%$ of patients on $40 \mathrm{mg}$ weekly achieving a $75 \%$ reduction in the PASI. ${ }^{43}$

Onercept is a recombinant, unmodified, fully human soluble type I p55 TNF $\alpha$ receptor. It is administered as a 
$150 \mathrm{mg}$ dose subcutaneously three times a week. In phase II psoriasis trials, 54\% of patients achieved a PASI 75 after 12 weeks of therapy. ${ }^{44}$ Phase III trials are currently underway.

\section{RETINOIDS}

Acitretin is an oral retinoid approved for the treatment of psoriasis. It is most effective as monotherapy for pustular psoriasis, rather than for chronic plaque, guttate, or erythrodermic psoriasis. ${ }^{45}$ Acitretin has not been shown to be effective in treating PsA. The initial dose of acitretin monotherapy is $25-50 \mathrm{mg}$ per day. ${ }^{46}$ Acitretin may be combined with phototherapy (UVB or PUVA), ${ }^{47-49}$ topical calcipotriene, $^{50}$ oral methotrexate, or ciclosporin. Like all retinoids, it is highly teratogenic and is pregnancy category $\mathrm{X}$. Acitretin has a serum half-life of 50 hours, but concomitant consumption of ethanol and acitretin may cause acitretin to be converted to its prodrug etretinate. Etretinate can be detected in the serum for up to two years, posing long term risk of teratogenicity. Therefore, acitretin should not be administered to women who may not be reliably compliant with contraception for three years after cessation of the drug. In women of childbearing potential, isotretinoin, a retinoid with a much shorter half-life, may be given at doses of $1.5 \mathrm{mg} / \mathrm{kg} / \mathrm{day}$. Side effects associated with these drugs include cheilitis, skin peeling, alopecia, xerosis, rhinitis, nail dystrophy, epistaxis, sticky skin, retinoid dermatitis, myalgias, pseudotumour, hyperostosis, decreased night vision, slowed wound healing, hyperlipidaemia (25-50\%), hepatotoxicity $(33 \%$ of patients show transient increase in liver function tests), and gastrointestinal symptoms. Unlike with isotretinoin, depression has not been reported in association with acitretin. The efficacy of isotretinoin for psoriasis has not been studied, either singly or in combination, under controlled and properly powered studies.

Oral tazarotene is a newer retinoid under evaluation for the treatment of moderate to severe psoriasis. It is administered as a daily dose of $4.5 \mathrm{mg}$. In clinical trials, oral tazarotene shared only a few of the retinoid associated mucocutaneous side effects-for example, cheilitis. It also showed no dose related effect on liver function tests and serum lipids. ${ }^{51-52}$ There has been no reported association with depression; with a short half-life (6.68-11.8 hours), it may reduce the concern of long term teratogenicity, allowing women of childbearing potential access to retinoid therapy with appropriate pregnancy prevention programmes. ${ }^{51} 52$

\section{OTHER THERAPIES}

Systemic therapies that have not been approved by the FDA are used less commonly in the treatment of psoriasis. These include hydroxyurea, ${ }^{53}$ mycophenolate mofetil, ${ }^{54}$ 6-thioguanine, ${ }^{55}$ sulfasalazine, ${ }^{56}$ and azathioprine, ${ }^{57}$ as monotherapy or in combination - on rotational or sequential regimens. ${ }^{58}$

Topical immunomodulators (pimecrolimus and tacrolimus) offer an advantage over corticosteroids for treating intertriginous and facial skin. They avoid cutaneous atrophy and acneiform eruptions that are likely to occur with corticosteroid use. ${ }^{59-61}$

\section{Phototherapy}

UV light is thought to exert its immunomodulatory effects via acute and subacute changes. Acutely, it induces membrane damage, production of cytoplasmic transcription factors, and isomerisation of urocanic acid. Subacute changes include alteration of the APC population and modification of cell-cell signalling. The general effect is a shift in the cytokine profile from Th 1 to Th 2 type cytokines. ${ }^{62}$

Phototherapy, PUVA or UVB, is commonly used in combination with other systemic treatments, particularly retinoids, ${ }^{45} 46{ }^{63}{ }^{64}$ which may in fact help reduce the potential for skin cancer inherent in phototherapy. Methotrexate has also been used in combination with UVB and PUVA. ${ }^{65} 66$ Combination regimens employing the biological agents with phototherapy may also yield additive or synergistic effects. Further information on phototherapy and other traditional forms of PsA treatment can be found in this supplement in the report by Lebwohl et al. ${ }^{67}$

\section{FUTURE DIRECTIONS}

Research in the past decade has brought much progress in the understanding of the immunopathogenesis and genetics of psoriasis, leading to the development of more targeted therapies. Systemic biological agents that target $\mathrm{T}$ cells and cytokines offer new hope to psoriasis patients who suffer significant impact on their quality of life. In addition to biological agents, there are many other promising therapeutic strategies including angiogenesis inhibitors, new retinoids, oral pimecrolimus, lasers, and photodynamic therapies. As further research identifies new therapeutic targets, collaboration between scientists, clinicians, industry, and patients will continue to advance our understanding of this disease and significantly improve the quality of life of our patients.

\section{Authors' affiliations}

L S Winterfield, Department of Dermatology, University of Texas Southwestern Medical School, Dallas, TX, USA

A Menter, Baylor University Medical Center, Dallas, TX, USA K Gordon, Loyola University, Stritch School of Medicine, Chicago, IL, USA

A Gottlieb, UMDNJ-Robert Wood Johnson Medical School, Piscataway, NJ, USA

Competing interests: Drs Gordon, Gottlieb, and Menter do not own stock in any of the pharmaceutical companies mentioned herein. Dr Gordon has consultancy and/or research relationships with Abbott, Amgen, Biogen Idec, Centocor, and Genentech. Dr Gottlieb has consultancy and/or research relationships with Biogen Idec, Amgen, Genentech, Centocor, Abbott, Novartis, Allergan, Warner-Chilcott, and Ligand. She is on the Speakers' Bureau for Biogen Idec, Amgen, and Wyeth. Dr Menter has consultancy and/or research relationships with Abbott, Allergan, Allermed, Amgen, Astralis, Berlex, Biogen, Centocor, Corixa, Dermik, Dow, Ferndale, Fujisawa, Genentech, Medicis, Novartis, Serono, Thermosurgery, and XOMA.

Correspondence to: $\operatorname{Dr} A$ Menter, 5310 Harvest Hill Road, Suite 260, Dallas, Texas 75230; amresearch@texasderm.com

\section{REFERENCES}

1 Christophers E. Psoriasis-epidemiology and clinical spectrum. Clin Exp Dermatol $2001 ; 26: 314-20$.

2 Fleischer AB Jr, Feldman SR, Rapp SR, Reboussin DM, Exum ML, Clark AR, et al. Disease severity measures in a population of psoriasis patients: the symptoms of psoriasis correlate with self-administered psoriasis area severity index scores. J Invest Dermatol 1996;107:26-9.

3 Finlay AY, Kelly SE. Psoriasis - an index of disability. Clin Exp Dermatol 1987; 12:8-11.

4 Finlay AY. Quality of life assessments in dermatology. Semin Cutan Med Surg 1998;17:291-6.

5 McKenna KE, Stern RS. The outcomes movement and new measures of the severity of psoriasis. J Am Acad Dermatol 1996;34:534-8.

6 Ashcroft DM, Li Wan Po A, Williams HC, Griffiths CE. Quality of life measures in psoriasis: a critical appraisal of their quality. J Clin Pharm Ther 1998;23:391-8.

7 Rapp SR, Exum ML, Reboussin DM, et al. The physical, psychological, and social impact of psoriasis. J Health Psychol 1997;2:525-37.

8 Rapp SR, Feldman SR, Exum ML, Fleischer AB Jr, Reboussin DM. Psoriasis causes as much disability as other major medical diseases. J Am Acad Dermatol 1999;41:401-7.

9 Krueger G, Feldman SR, Camisa C, Duvic M, Elder JT, Gottlieb AB, et al. Two considerations for patients with psoriasis and their clinicians: What defines mild, moderate, and severe psoriasis? What constitutes a clinically significant improvement when treating psoriasis? J Am Acad Dermatol 2000;43:281-5.

10 Nickoloff BJ, Kunkel SL, Burdick M, Strieter RM. Severe combined immunodeficiency mouse and human psoriatic skin chimeras. Validation of a new animal model. Am J Pathol 1995;146:580-8. 
11 Boehncke WH, Dressel D, Zollner TM, Kaufmann R. Pulling the trigger on psoriasis. Nature 1996;379:777.

12 Gilhar A, David M, Ullmann Y, Berkutski T, Kalish RS. T-lymphocyte dependence of psoriatic pathology in human psoriatic skin grafted to SCID mice. J Invest Dermatol 1997; 109:283-8.

13 Sugai J, lizuka M, Kawakubo Y, Ozawa A, Ohkido M, Ueyama Y, et al. Histological and immunocytochemical studies of human psoriatic lesions transplanted onto SCID mice. J Dermatol Sci 1998;17:85-92.

14 Yamamoto T, Matsuuchi M, Katayama I, Nishioka K. Repeated subcutaneous injection of staphylococcal enterotoxin B-stimulated lymphocytes retains epidermal thickness of psoriatic skin-graft onto severe combined immunodeficient mice. J Dermatol Sci 1998;17:8-14.

15 Mueller W, Herrmann B. Cyclosporin A for psoriasis. N Engl J Med 1979:301:555

16 Ellis CN, Gorsulowsky DC, Hamilton TA, Billings JK, Brown MD, Headington JT, et al. Cyclosporine improves psoriasis in a double-blind study. JAMA 1986;256:3110-16.

17 Waters CA, Snider CE, Itoh K, Poisson L, Strom TB, Murphy JR, et al. DAB486IL-2 (IL-2 toxin) selectively inactivates high-affinity IL-2 receptorbearing human peripheral blood mononuclear cells. Ann N Y Acad Sci $1991 ; 636: 403-5$

18 Gottlieb SL, Gilleaudeau P, Johnson R, Estes L, Woodworth TG, Gottlieb AB, et al. Response of psoriasis to a lymphocyte-selective toxin (DAB389|L-2) suggests a primary immune, but not keratinocyte, pathogenic basis. Nat Med 1995; 1:442-7.

19 Bagel J, Garland WT, Breneman D, Holick M, Littlejohn TW, Crosby D, et al. Administration of DAB389IL-2 to patients with recalcitrant psoriasis: a doubleblind, phase II multicenter trial. J Am Acad Dermatol 1998:38:938-44.

20 Bjerke JR, Krogh HK, Matre R. Characterization of mononuclear cell infiltrates in psoriatic lesions. J Invest Dermatol 1978;71:340-3.

21 Bos JD, Hulsebosch HJ, Krieg SR, Bakker PM, Cormane RH. Immunocompetent cells in psoriasis. In situ immunophenotyping by monoclonal antibodies. Arch Dermatol Res 1983;275:181-9.

22 Kreuger JG, Bowcock A. Psoriasis pathophysiology: current concepts of pathogenesis. Ann Rheum Dis 2005;64(suppl II):ii30-6.

23 Singri P, West DP, Gordon KB. Biologic therapy for psoriasis: the new therapeutic frontier. Arch Dermatol 2002;138:657-63.

24 Chisholm PL, Williams CA, Jones WE, Majeau GR, Oleson FB, BurrusFischer $B$, et al. The effects of an immunomodulatory LFA3-lgG1 fusion protein on nonhuman primates. Ther Immunol 1994;1:205-16.

25 Miller GT, Hochman PS, Meier W, Tizard R, Bixler SA, Rosa MD, et al. Specific interaction of lymphocyte function-associated antigen 3 with CD2 can inhibit T cell responses. J Exp Med 1993;178:211-22.

26 Meier W, Gill A, Rogge M, Dabora R, Majeau GR, Oleson FB, et al. Immunomodulation by LFA3TIP, and LFA-3/IgG1 fusion protein: cell line dependent glycosylation effects on pharmacokinetics and pharmacodynamic markers. Ther Immuno 1995:2:159-71.

27 Majeau GR, Meier W, Jimmo B, Kioussis D, Hochman PS. Mechanism of lymphocyte function-associated molecule 3-lg fusion proteins inhibition of $T$ cell responses. Structure/function analysis in vitro and in human CD2 transgenic mice. J Immunol 1994:152:2753-67.

28 Lebwohl M, Christophers E, Langley R, Ortonne JP, Roberts J, Griffiths CE; Alefacept Clinical Study Group. An international, randomized, double-blind, placebo-controlled phase 3 trial of intramuscular alefacept in patients with chronic plaque psoriasis. Arch Dermatol 2003;139:719-27.

29 Kraan MC, van Kuijk AW, Dinant HJ, Goedkoop AY, Smeets TJ, de Rie MA, et al. Alefacept treatment in psoriatic arthritis: reduction of the effector $\mathrm{T}$ cell population in peripheral blood and synovial tissue is associated with improvement of clinical signs of arthritis. Arthritis Rheum 2002;46:2776-84

30 Van Seventer GA, Shimizu Y, Horgan KJ, Luce GE, Webb D, Shaw S. Remote T cell co-stimulation via LFA-1/ICAM-1 and CD2/LFA-3: demonstration with immobilized ligand/mAb in monocyte-mediated co-stimulation. Eur J Immunol $1991 ; 21: 1711$

31 Werther WA, Gonzalez TN, O'Connor SJ, McCabe S, Chan B, Hotaling T, et al. Humanization of an anti-lymphocyte function-associated antigen (LFA)-1 monoclonal antibody and reengineering of the humanized antibody for binding to rhesus LFA-1. J Immunol 1996;157:4986-95.

32 Krueger J, Gottlieb A, Miller B, Dedrick R, Garovoy M, Walicke P. AntiCDI la treatment for psoriasis concurrently increases circulating T-cells and decreases plaque T-cells, consistent with inhibition of cutaneous T-cell trafficking. J Invest Dermatol 2000; 115:333.

33 Chamian F, Lin S, Novitskaya I, et al. Presence of "inflammatory" dendritic cells in psoriasis vulgaris lesions and modulation by efalizumab (anti-CD1 la). Poster presented at the 65th annual meeting of the Society for Investigative Dermatology, 29 April-1 May 2004, Providence, RI, USA

34 Gordon KB, Papp KA, Hamilton TK, Walicke PA, Dummer W, Li N, et al. Efalizumab Study Group. Efalizumab for patients with moderate to severe plaque psoriasis: a randomized controlled trial. JAMA 2003;290:3073-80. Erratum in: JAMA 2004;291:1070.

35 Gaylor ML, Duvic M. Generalized pustular psoriasis following withdrawal of efalizumab. J Drugs Dermatol 2004;3:77-9.

36 Schlaak JF, Buslau M, Jochum W, Hermann E, Girndt M, Gallati H, et al. T cells involved in psoriasis vulgaris belong to the Th1 subset. J Invest Dermatol 1994; 102:145-9.

37 Ohta Y, Hamada Y, Katsuoka K. Expression of IL-18 in psoriasis. Arch Dermatol Res $2001 ; 293: 334-42$
38 Gottlieb AB, Evans R, Li S, Dooley LT, Guzzo CA, Baker D, et al. Infliximab induction therapy in patients with severe plaque-type psoriasis: a randomized, double-blind, placebo-controlled trial. J Am Acad Dermatol (in press).

39 Gottlieb AB, Matheson RT, Lowe N, Krueger GG, Kang S, Goffe BS, et al. A randomized trial of etanercept as monotherapy for psoriasis. Arch Dermatol 2003;139: 1627-32; discussion 1632

40 Leonardi CL, Powers JL, Matheson RT, Goffe BS, Zitnik R, Wang A, et al. Etanercept Psoriasis Study Group. Etanercept as monotherapy in patients with psoriasis. N Engl J Med 2003;349:2014-22.

41 Moreland LW, Schiff M, Cohen S, Fleischmann RM, Baumgartner S, Burge D, et al. Safety and efficacy of up to 5 years of etanercept (Enbrel) therapy in rheumatoid arthritis. Presented at the European League Against Rheumatism 12-15 June 2002.

42 Mease PJ, Goffe BS, Metz J, VanderStoep A, Finck B, Burge DJ. Etanercept in the treatment of psoriatic arthritis and psoriasis: a randomized trial. Lancet 2000;356:385-90

43 Chen DM, Gordon K, Leonardi MD, et al. Adalimumab efficacy and safety in patients with moderate to severe chronic plaque psoriasis: Preliminary findings from a 12-week dose-ranging trial. J Am Acad Dermatol 2004;50(3 Pt II), and PS 491; Ps.

44 Menter A. Onercept. Presented at the International Psoriasis Society Meeting, June 2003, New York.

45 Lowe NJ, Lazarus V, Matt L. Systemic retinoid therapy for psoriasis. J Am Acad Dermatol 1988;19:186-91

46 Ling MR. Acitretin: optimal dosing strategies. J Am Acad Dermatol 1999:41:S13-S17.

47 Lebwohl M. Acitretin in combination with UVB or PUVA. J Am Acad Dermatol 1999;41:S22-S24.

48 Lowe NJ, Prystowsky JH, Bourget T, Edelstein J, Nychay S, Armstrong R. Acitretin plus UVB therapy for psoriasis. Comparisons with placebo plus UVB and acitretin alone. J Am Acad Dermatol 1991:24:591-4.

49 Lebwohl M, Drake L, Menter A, Koo J, Gottlieb AB, Zanolli M, et al. Consensus conference: acitretin in combination with UVB or PUVA in the treatment of psoriasis. J Am Acad Dermatol 2001;45:544-53.

50 Ashcroft DM, Li Wan Po A, Williams HC, Griffiths CE. Combination regimens of topical calcipotriene in chronic plaque psoriasis: systematic review of efficacy and tolerability. Arch Dermatol 2000;136:1536-43.

51 Lowe NJ, Lew-Kaya D, Walker PS. Safety of oral tazarotene in nodulocystic acne. Presented at the 62nd annual meeting of the American Academy of Dermatology, 6-11 February 2004, Washington DC, poster no. 67

52 Walker PS, Gottlieb A, Guenther L, et al. Safety of oral tazarotene in moderate to severe plaque psoriasis. Presented at the 62 nd annual meeting of the American Academy of Dermatology, 6-11 February 2004, Washington DC, poster no. 595 .

53 Leavell UW Jr, Yarbro JW. Hydroxyurea. A new treatment for psoriasis. Arch Dermatol 1970;102:144-50

54 Jones EL, Epinette WW, Hackney VC, Menendez L, Frost P. Treatment of psoriasis with oral mycophenolic acid. J Invest Dermatol 1975;65:537-42.

55 Zackheim HS, Glogau RG, Fisher DA, Maibach HI. 6-Thioguanine treatment of psoriasis: experience in 81 patients. J Am Acad Dermatol 1994;30:452-8.

56 Gupta AK, Grober JS, Hamilton TA, Ellis CN, Siegel MT, Voorhees JJ, et al. Sulfasalazine therapy for psoriatic arthritis: a double blind, placebo controlled trial. J Rheumatol 1995;22:894-8.

57 Scerri L. Azathioprine in dermatological practice. An overview with special emphasis on its use in non-bullous inflammatory dermatoses. Adv Exp Med Biol 1999;455:343-8.

58 Menter MA, See JA, Amend WJ, Ellis CN, Krueger GG, Lebwohl M, et al. Proceedings of the Psoriasis Combination and Rotation Therapy Conference. Deer Valley, Utah, Oct. 7-9, 1994. J Am Acad Dermatol 1996;34:315-21, Erratum in: J Am Acad Dermatol 1996;34:1029.

59 Yamamoto T, Nishioka K. Topical tacrolimus: an effective therapy for facial psoriasis. Eur J Dermatol 2003;13:471-3.

60 Mrowietz U, Wustlich S, Hoexter G, Graeber M, Brautigam M, Luger T. An experimental ointment formulation of pimecrolimus is effective in psoriasis without occlusion. Acta Derm Venereol 2003;83:351-3.

61 Freeman AK, Linowski GJ, Brady C, Lind L, Vanveldhuisen P, Singer G, et al. Tacrolimus ointment for the treatment of psoriasis on the face and intertriginous areas. J Am Acad Dermatol 2003;48:564-8.

62 Duthie MS, Kimber I, Norval M. The effects of ultraviolet radiation on the human immune system. Br J Dermatol 1999;140:995-1009.

63 Tanew A, Guggenbichler A, Honigsmann H, Geiger JM, Fritsch P. Photochemotherapy for severe psoriasis without or in combination with acitretin: a randomized, double-blind comparison study. J Am Acad Dermatol $1991 ; 25: 682-4$

64 lest J, Boer J. Combined treatment of psoriasis with acitretin and UVB phototherapy compared with acitretin alone and UVB alone. Br J Dermatol 1989; 120:665-70.

65 Paul BS, Momtaz K, Stern RS, Arndt KA, Parrish JA. Combined methotrexateultraviolet B therapy in the treatment of psoriasis. J Am Acad Dermatol 1982;7:758-62.

66 Morison WL, Momtaz K, Parrish JA, Fitzpatrick TB. Combined methotrexatePUVA therapy in the treatment of psoriasis. J Am Acad Dermatol 1982;6:46-51

67 Lebwohl M, Ting PT, Koo JYM. Psoriasis treatment: traditional therapy. Ann Rheum Dis 2005;64(suppl II):ii83-6 